\title{
Activation of $h s r 203$, a Plant Gene Expressed During Incompatible Plant-Pathogen Interactions, Is Correlated with Programmed Cell Death
}

\author{
Dominique Pontier, ${ }^{1,3}$ Maurice Tronchet, ${ }^{1}$ Peter Rogowsky, ${ }^{2}$ Eric Lam, ${ }^{3}$ and Dominique Roby ${ }^{1}$ \\ ${ }^{1}$ Laboratoire de Biologie Moléculaire des Relations Plantes-Microorganismes, UMR CNRS / INRA 215, BP \\ 27, 31326 Castanet-Tolosan Cedex, France; ${ }^{2}$ RCAP, ENS Lyon, 46 Allée d'Italie, 69364 Lyon Cedex 07, \\ France; ${ }^{3} \mathrm{AgBiotech}$ Center, Foran Hall, Dudley Road, P.O. Box 231, Cook College, New Brunswick, NJ \\ 08903-0231, U.S.A. \\ Accepted 20 February 1998.
}

\begin{abstract}
hsr203J is a tobacco gene whose activation is rapid, highly localized, and specific for incompatible interactions between tobacco and the bacterial pathogen Ralstonia solanacearum. The effect of other hypersensitive response (HR)-inducing pathogens and elicitors has been tested with transgenic plants containing the $h s r 203 J$ promoter$G U S$ reporter gene fusion, and confirms the generality of the preferential inducibility of the $h s r 203 J$ gene promoter during incompatible interactions: bacterial and viral pathogens inducing an HR in tobacco were able to induce the promoter fusion, as were inducers of HR-like responses such as harpin, elicitins, and PopA1 proteins. A tomato hsr203 homologous cDNA was isolated (Lehsr203) and used to examine the effect of $a v r$ gene products on the expression of such genes. Lehsr 203 was shown to be rapidly and transiently induced in leaves of the tomato $C f-9$ line, following Avr9 product infiltration, but not in those of the $\boldsymbol{C f}$-O line. Among potential effectors of $\mathrm{HR}$ or resistance such as $\mathrm{H}_{2} \mathrm{O}_{2}$, salicylic acid, methyl jasmonate, and 2,6-dichloro-isonicotinic acid (INA), none is able to induce a significant increase in promoter activation. In contrast, heavy metals that cause leaf necrosis can trigger such an activation. In addition, hsr203-GUS fusion expression is detected in transgenic tobacco lines expressing the $b O$ gene and exhibiting spontaneous HR-like lesions. Taken together, these results demonstrate a strong correlation between $h s r 203$ and genetically controlled cell death in tobacco and tomato. The expression of this gene should be a useful marker for programmed cell death occurring in response not only to diverse pathogens, but also to diverse death-triggering extracellular agents.
\end{abstract}

In plants, one of the most efficient resistance reactions to pathogen attack is the so-called hypersensitive response (HR). It consists of rapid and localized cell death at the site of attempted infection, limiting further spread of the pathogen (Klement 1963). This cell suicide is conditioned by initial recognition events between host and pathogen, which are mediated by the plant resistance $(R)$ and microbial avirulence

Corresponding author: Dominique Roby (avr) genes (Flor 1971; Godiard et al. 1994). During the last few years, a considerable effort has been made to elucidate this phase of the interaction, leading to the identification and cloning of several $a v r$ and $R$ genes (Keen and Staskawicz 1988; Dangl 1995). In contrast, little is known about the processes that are required beyond the $R$ genes for the establishment of the HR. Although membrane potential changes, ion fluxes, and $\mathrm{H}_{2} \mathrm{O}_{2}$ production are characteristic early events (Goodman and Novacky 1994; Levine et al. 1994; HammondKosack and Jones 1996), their precise roles remain to be more fully established.

Cell death is an important physiological process in most multicellular organisms. It not only occurs during development, but also is used for protection against viral infections (Vaux 1993). This process is achieved through a genetic program that is conserved throughout much of evolution. The best molecular and genetic characterization of the cell death pathway has been performed in the nematode Caenorhabditis elegans; 14 genes have been identified, some of them involved in the control of cell death, such as ced-3, ced-4, and ced-9 (Osborne and Schwartz 1994). Documentation of the existence of such genes in plants comes from studies of "disease lesion mimic" mutants that develop HR lesions spontaneously (Greenberg and Ausubel 1993; Greenberg et al. 1994; Dietrich et al. 1994; Walbot et al. 1983). Further evidence has been provided by expression of foreign genes in transgenic plants in which HR-like lesions are observed (Culver and Dawson 1991; Wolter et al. 1993; Mittler et al. 1995), or by study of HR-inducing protein elicitors (Wei et al. 1992; He et al. 1993; Arlat et al. 1994; Bauer et al. 1995; Hammond-Kosack et al. 1994), such as AVR9, harpins, or PopA1. All these reports are in favor of the existence of cell death genes encoded by the plant genome and regulated by pathogen-related signals. Such genes would exhibit a highly specific program of activation: during the early steps of plant-pathogen interactions, specifically in response to avirulent pathogens and highly localized to the site of attempted infection.

A gene showing such a profile of activation has been identified in tobacco: hsr203J (Pontier et al. 1994). Its promoter is highly, rapidly, and specifically activated in response to HRinducing bacterial isolate, does not respond to various stress 
conditions, and is strongly dependent on hrp (hypersensitive response and pathogenicity) genes of the pathogenic bacterium Ralstonia solanacearum. The identification of the hsr203J gene in tobacco prompted us to examine the mechanistic relationship of this gene activation with the HR. Tomato, another member of the Solanaceae for which genetically well-defined pathosystems have been reported, has been used in parallel with tobacco as a model in this study.

The present analysis describes the isolation of an hsr203 homologous gene from tomato, which allows us to address the question of whether the hsr203 gene is activated during the HR mediated by $R / a v r$ genes in this species as well. We demonstrate that the expression of the Cladosporium fulvum avirulence $a v r 9$ gene product in a tomato line containing the $C f-9$ disease resistance gene leads to rapid $h s r 203 \mathrm{~J}$ gene activation. In addition, while various biotic and abiotic elicitors are not active, HR- or necrosis-inducing elicitors are able to trigger the $h s r 203 \mathrm{~J}$ gene in tobacco. In contrast, potential signals involved in the establishment of the $\mathrm{HR}$, such as $\mathrm{H}_{2} \mathrm{O}_{2}$, are not able to induce hsr203J. Taken together, these data suggest that this gene would be involved in the early steps of the HR. The generality of this gene activation during programmed cell death in response, not only to different pathogens but also to diverse death-triggering agents, supports the existence of a strong relationship between $h s r 203$ and genetically controlled cell death.

\section{RESULTS}

\section{hsr203J expression in tobacco in response to HR-inducing pathogens and elicitors.}

Previous studies showed that the hsr203J gene was expressed preferentially during incompatible interactions between tobacco and $R$. solanacearum, a vascular bacterial pathogen of different plant species including members of the Solanaceae. Using transgenic tobacco lines containing an hsr203J gene promoter-GUS fusion previously described (Pontier et al. 1994), we found (Fig. 1) that this gene is also
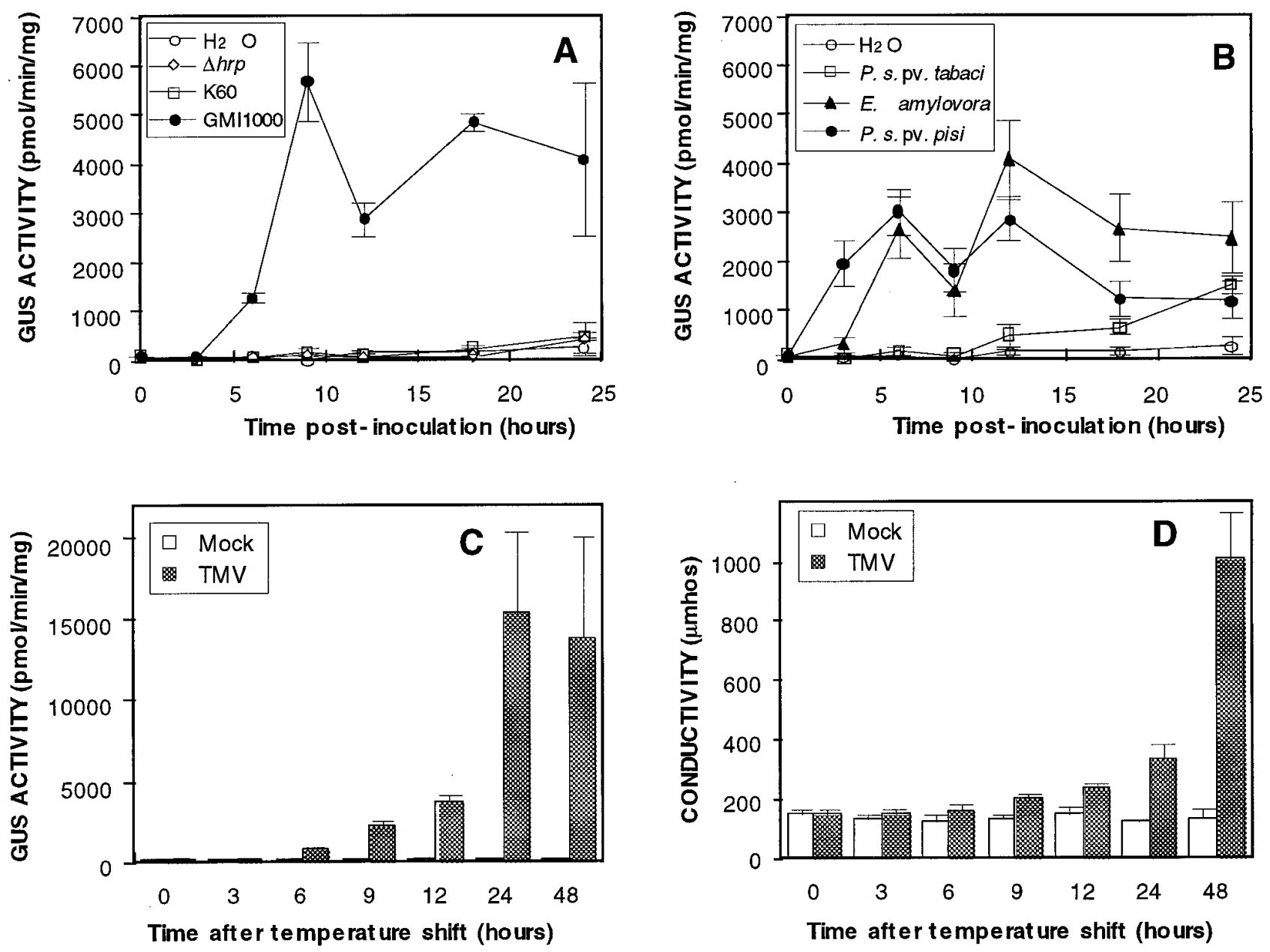

Fig. 1. Time course of $h s r 203 \mathrm{~J}$ promoter activation in transgenic tobacco plants inoculated with bacterial or fungal pathogens. A and $\mathbf{B}$, Four leaves from two transformants were locally infiltrated with water or with bacterial suspensions $\left(10^{8} \mathrm{CFU} / \mathrm{ml}\right)$ as indicated. A, Data obtained with the control Ralstonia solanacearum strains ( $\Delta \mathrm{hrp}, \mathrm{K} 60$, and GMI 1000). B, Data obtained in the same period for the other bacterial strains tested. Infiltrated areas were harvested at indicated time points and $\beta$-glucuronidase (GUS) activity was measured. Data shown represent mean and standard deviation of four independent measurements. C and D, Transgenic plants containing the hsr203J-GUS fusion and the $N$ resistance gene were inoculated with water (mock) or with tobacco mosaic virus (TMV) and incubated in a growth chamber at $30^{\circ} \mathrm{C}$ for 3 days. Leaf disks were collected at different time points after shift at $22^{\circ} \mathrm{C}$ as indicated on graphs. GUS activity was measured on 5 leaf disks (C) and formation of the lesions was determined by measuring leakage of ions from 5 other leaf disks $(\mathbf{D})$. Data presented are mean and standard deviation of three individual plants. 
expressed in response to different bacterial and viral avirulent pathogens (Table 1). Besides $R$. solanacearum (Fig.1A), high $\beta$-glucuronidase (GUS) activities were found in transgenic tobacco plants inoculated with Pseudomonas syringae pv. pisi and Erwinia amylovora, two bacterial pathogens inducing an HR in tobacco (Fig. 1B). Although the kinetics are different, the induction levels of the $h s r 203 \mathrm{~J}$ promoterGUS fusion are similar in all cases (30- to 50-fold stimulation over control values). In contrast, much lower levels of GUS activity were measured after infiltration with virulent strains, even upon long incubation times. The introduction by crossing of the $N$ resistance gene in transgenic plants containing the hsr203-GUS fusion allowed us to examine whether the $h s r 203 \mathrm{~J}$ gene could also be activated during a virus-induced HR. GUS activity measurements indicate that the $h s r 203 \mathrm{~J}$ promoter is activated 6 to $12 \mathrm{~h}$ after the temperature shift (Fig. 1C), nearly in the same period as the increase of conductivity, a marker of cell death (Fig. 1D). No GUS activity nor variation in ion leakage could be detected in mock-inoculated tobacco plants.

Harpin, an HR-inducing elicitor, was previously shown to trigger the expression of the hsr203J-GUS fusion in tobacco (Pontier et al. 1994). Tobacco leaves were locally infiltrated with Pseudomonas fluorescens with or without the hrpZ gene of $P$. syringae pv. syringae, a gene encoding the harpin $_{\text {Pss }}$ (Huang et al. 1988). Histochemical GUS detection results in the staining of the area infiltrated with the harpinproducing strain (Fig. 2). This data demonstrates the highly localized nature of the induction of $h s r 203 \mathrm{~J}$ in response to this elicitor. Other HR-inducing elicitors, such as PopA, cryptogein, and capsicein, isolated from bacterial and fungal pathogens, were also tested (Fig. 3). PopA1, an extracellular protein characterized from the supernatant of $R$. solanacearum strain GMI1000 (Arlat et al. 1994), appeared to trigger the expression of the GUS fusion at high levels, similarly to harpin, although the induction process seems more rapid in the case of PopA1. Fungal proteins from Phytophthora spp. called elicitins were comparatively less efficient elicitors. Cryptogein was more active than capsicein in inducing leaf necrosis. Six hours post treatment, GUS activities comparable to those measured with harpin or PopA1 could be observed. However, this level of activation of the $h s r 203 \mathrm{~J}$ promoter was not sustained, and decreased at later time points. Controls, including water, buffer with phenylmethylsulfonyl fluoride (PMSF, a protease inhibitor used for treatment with harpin), or a fungal elicitor of de- fense responses in some plant species, the hepta, $\beta$ glucoside from Phytophthora megasperma pv. glycineae (Sharp et al. 1984), were also performed: no or very low GUS activity could be detected with these treatments.

Taken together, these data demonstrate that the hsr203J gene is activated in tobacco in response to a variety of HRinducing pathogens and HR-like inducing elicitors. Only a very low level, if any, of $h s r 203 \mathrm{~J}$ expression, in response to virulent pathogens or elicitors of defense responses but not of cell death, was observed, indicating a close relationship between $h s r 203 \mathrm{~J}$ activation and hypersensitive cell death.

\section{Expression of an $h s r 203$ gene homolog in tomato is observed in response to the $a v{ }^{9}$ gene product in the $\boldsymbol{C f}$-9 tomato line, but not in the $\boldsymbol{C f}$-0 line.}

In order to investigate the role of $a v r$ and $R$ genes in the specific activation of $h s r 203$ in response to avirulent pathogens, we first isolated a homolog from tomato, another member of the Solanaceae for which genetically defined pathosystems have been reported. For this purpose, a cDNA library from tomato was screened with the cDNA pNt203 and a cDNA homologous to the tobacco hsr203J gene was isolated and sequenced. Sequence analysis of this clone, named Lehsr 203, revealed an open reading frame of 335 amino acids that shows $93 \%$ similarity and $86 \%$ identity with the coding sequence of $h s r 203 \mathrm{~J}$ (Fig. 4). This clone was used as a probe for Northern (RNA) blot experiments in tomato in the context of a well-studied pathosystem: the interaction between tomato and the obligate, biotrophic, fungal pathogen Cladosporium fulvum.

Northern analysis was used to investigate the expression of Lehsr203 in two near-isogenic lines of tomato differing by the presence of the resistance gene $C f-9$, in response to the AVR9 peptide. Upon leaf infiltration with intercellular fluids containing AVR9, a strong and rapid accumulation of Lehsr 203 was observed only in $C f-9$ plants (Fig. 5), not in $C f$ - 0 plants. The level of transcript accumulation was extremely high but transient, since only weak hybridization signals were detected before or after $3 \mathrm{~h}$ post treatment, the time point at which the expression level was maximal. In addition, Lehsr 203 expression clearly precedes the establishment of the HR, since the appearance of the necrotic lesion only became visible at about $12 \mathrm{~h}$ after infiltration.

These results show that $h s r 203$ gene activation is not only closely linked to the development of the HR, but also can reflect the action of specific $a v r$ and $R$ genes.

Table 1. Bacterial, viral, and fungal pathogens used in this study

\begin{tabular}{|c|c|c|c|}
\hline Pathogens & Source or reference & Plant used in this study & Plant response \\
\hline \multicolumn{4}{|l|}{ Pseudomonas solanacearum } \\
\hline GMI 1000 & Boucher et al. 1985 & Tobacco & Hypersensitive response (HR) \\
\hline K 60 & Lozano and Sequeira 1970 & Tobacco & Disease \\
\hline$\Delta \mathrm{hrp}$ & C. Boucher, unpublished & Tobacco & No symptoms \\
\hline \multicolumn{4}{|l|}{ Pseudomonas syringae } \\
\hline pv. pisi (CFBP 2105) & INRA, Angers, France & Tobacco & HR \\
\hline pv. tabaci (CFBP 2106) & INRA, Angers, France & Tobacco & Disease \\
\hline \multicolumn{4}{|l|}{ Pseudomonas fluorescens } \\
\hline strain 55 (pHIR11) & Huang et al. 1988 & Tobacco & HR \\
\hline strain 55 & Huang et al. 1988 & Tobacco & No symptoms \\
\hline Erwinia amylovora strain 1430 & Paulin and Samson 1973 & Tobacco & HR \\
\hline \multirow[t]{2}{*}{ Tobacco mosaic virus strain U1 } & Holt et al. 1990 & Tobacco (Samsun NN) & HR \\
\hline & & Tobacco (Bottom Special) & Disease \\
\hline
\end{tabular}




\section{hsr 203J gene expression in response to potential effectors of HR, cell death, or resistance.}

To determine precisely the expression patterns of $h s r 203 \mathrm{~J}$ with respect to the development of the HR, the appearance of necrotic lesions, or resistance mechanisms, different compounds were tested on transgenic tobacco plants containing the $h s r 203 J-G U S$ fusion (Table 2). Compared with the induction levels measured in response to $R$. solanacearum (45- to 210 -fold increase over the control), none of the compounds tested was able to significantly activate the $h s r 203 \mathrm{~J}$ promoter. Phytohormones such as auxin, cytokinin, or ethylene (ACC) were not able to induce GUS activity significantly over the control, although at least one of them (ethylene) is known to be implicated in plant stress responses. In addition to these phytohormones, compounds implicated as signals in defense or resistance responses such as hydrogen peroxide, salicylic acid, or methyl jasmonate were also tested. Exogenous $\mathrm{H}_{2} \mathrm{O}_{2}$ was unable to induce any GUS activity. 3,amino-1,2,4-triazole (ATZ), an inhibitor of catalases, did not efficiently potentiate the action of $\mathrm{H}_{2} \mathrm{O}_{2}$, as the observed increase in GUS activity could be attributed at least in part to the application of ATZ alone. Salicylic acid did not trigger any increase in the activity of the gene reporter, and methyl jasmonate was also found to be completely inactive. Similar results were obtained by treatment of the transgenic plants with inducers of systemic resistance (INA and methyl-INA), or an inhibitor of protein phosphatases (okadaic acid) or its analog. In parallel, all these compounds were tested on transgenic tobacco lines containing an $m s r$ (multiple stimulus response) gene promoter (Gough et al. 1995) or an ethylene biosynthesis gene promoter (Lasserre et al. 1996) and found active. In contrast to these treatments, heavy metals such as copper sulfate or lead nitrate, which have been shown to be toxic and cause cell death (Lummerzheim et al. 1995; Ryerson and Heath 1996), induced some increase in GUS activity. This was correlated with the appearance of necrotic spots along the veins at $100 \mu \mathrm{M}$ for $\mathrm{CuSO}_{4}$, and on the whole surface of the leaf at a concentration of $500 \mu \mathrm{M}$ or $10 \mathrm{mM}$ for $\mathrm{CuSO}_{4}$ or $\mathrm{PbNO}_{3}$, respectively.

The occurrence of mutants that develop spontaneous lesions similar to the HR suggested that a cell death pathway could be spontaneously activated. These plants present an additional

A

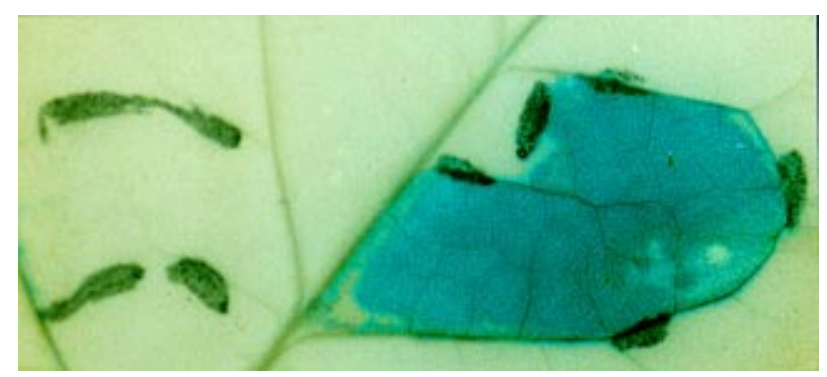

Fig. 2. Histochemical localization of $\beta$-glucuronidase (GUS) gene expression in a transgenic tobacco leaf inoculated with harpin-producing bacteria. An undetached leaf was infiltrated in a small region $\left(1 \mathrm{~cm}^{2}\right)$ with a syringe without a needle, with (A) wild-type Pseudomonas fluorescens or (B) hrpZ-expressing $P$. fluorescens. Black lines indicate borders of infiltrated area. Tissue sample was collected $9 \mathrm{~h}$ after infiltration and stained for GUS activity. Magnification of the photograph is $\times 2$. model system for studying the expression pattern of $h s r 203 \mathrm{~J}$ in relation to the activation of the cell death process. Transgenic plants expressing the $b O$ gene develop such lesions, depending on their developmental stage (Mittler et al. 1995). Crosses between $b O$ transgenic tobacco plants and transgenic ones containing an $h s r 203 \mathrm{~J}$ promoter-GUS fusion have been performed and the progenies analyzed. Histochemical GUS detection in lower leaves showing lesions resulted in a blue staining inside young, developing lesions, concomitant with the appearance of fluorescent phenolic compounds (Fig. 6A) and of a few cell layers surrounding older, bigger lesions (Fig. $6 \mathrm{~B})$. No staining was visible elsewhere in the same leaves, nor in youngest leaves showing no lesion at all.

\section{DISCUSSION}

A number of plant defense genes have been shown to be activated rapidly during plant-pathogen interactions, and often preferentially and early during incompatible interactions (Kombrink and Somssich 1995). But they are also expressed during compatible interactions and in response to various stresses (Bowles 1990), even in response to nonpathogenic microbes (Godiard et al. 1990; Jakobek and Lindgren 1993). Using the differential screening procedure, we isolated genes that show hrp-dependent induction (Marco et al. 1990); among these, $h s r 203 \mathrm{~J}$ has been shown, with the GUS reporter gene fusion system, to exhibit a rapid, high-level, localized, and specific activation in response to an HR-inducing bacterial pathogen (Pontier et al. 1994). In parallel, other genes, such as Eli3 (Kiedrowski et al. 1992) and AIG1 (Reuber and

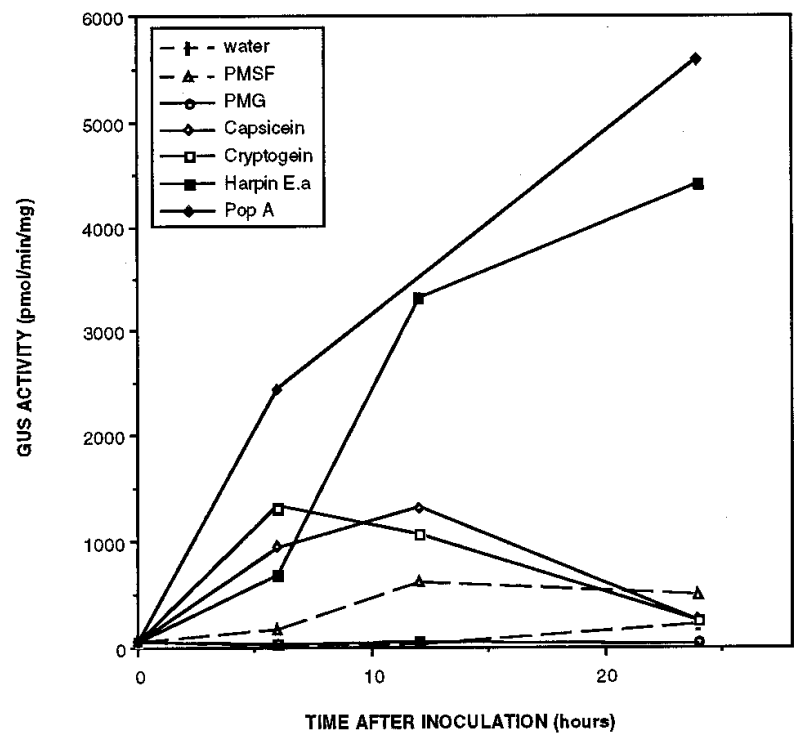

Fig. 3. Time course of $h s r 203 \mathrm{~J}$ promoter activation in transgenic tobacco plants inoculated with bacterial or fungal elicitors. Transgenic tobacco leaves were locally infiltrated with a $1 \mu \mathrm{M}$ solution of the heptasaccharide from Phytophthora megasperma (PMG), a $500 \mathrm{ng} / \mathrm{ml}$ solution of PopA, or water (control). Capscicein $(10 \mu \mathrm{g} / \mathrm{ml})$, cryptogein $(10 \mu \mathrm{g} / \mathrm{ml})$, and harpin (an impure preparation [Wei et al. 1992] used at dilution 1/50) were infiltrated in the presence of a protease inhibitor PMSF (1.5 $\mathrm{mM})$. As a control, PMSF $(1.5 \mathrm{mM})$ alone was infiltrated. For each time point, four infiltrated areas from two independent transformants were harvested and $\beta$-glucuronidase (GUS) activity was measured. Data correspond to mean of two independent experiments. 
Ausubel 1996) from Arabidopsis thaliana, or hinl from tobacco (Gopalan et al. 1996), were identified and shown to belong to a class of pathogen-induced genes that are specifically activated by signaling molecules generated during an HR. Eli3 activation has been demonstrated to be dependent on the RPM1 resistance locus, while AIG1 shows RPS2- and avrRpt2-dependent induction. Hin1, which has been recently isolated by a subtractive hybridization method, was found to be induced in a bacterial hrp gene-dependent manner, and in response to bacterial strains containing the avrPto gene.

In the present work, we demonstrate that the specific activation of $h s r 203 \mathrm{~J}$ could be generalized in tobacco in response to various HR-inducing pathogens or elicitors, and that a homologous gene isolated from tomato, Lehsr203, exhibits similar characteristics of regulation. Taking advantage of the existence of genetically well-defined pathosystems for this species, activation of Lehsr 203 has been shown to be specifically induced via $a v r / R$ genes. Finally, the relationships between the activation of $h s r 203 \mathrm{~J}$ and one example of a specific cell death have been investigated. hsr203J was shown to be closely linked with genetically programmed cell death observed in the case of gene-for-gene interactions or in lesionmimic mutants, and also with necrosis caused by abiotic compounds such as heavy metals.

\section{hsr203 and host-pathogen specificity.}

We previously reported that $h s r 203 \mathrm{~J}$ gene activation was dependent on bacterial hrp genes and induced by the harpin produced by Erwinia amylovora (Pontier et al. 1994). hrp genes and elicitors such as harpins play a key role in the interactions between plants and pathogens, since mutants deficient for these genes are impaired both in their ability to cause disease on host plants and in their ability to induce the HR on resistant or nonhost plants (Boucher et al. 1992). However, they are not the basis for host-pathogen specificity. Recent reports based on sequence homologies and functional evidence propose that they encode a secretion pathway that allows the transit of bacterial signal molecules such as harpins and also avirulence gene products (Van Gijsegem et al. 1993). Our previous data have been confirmed here by saprophytic bacterial strains either producing or not the harpin from $P$. $s y$ ringae pv. syringae (Huang et al. 1988): a rapid and highly localized expression of $h s r 203$ was detected, mimicking what was observed in response to avirulent bacteria. A recent report of Gopalan et al. (1996) indicates the induction of hsr203J in response to hrp mutants of $P$. syringae pv. syringae 61 and by $P$. syringae pv. tabaci WF4 at late time points. The authors explain this result by the use of a different pathosystem. Another possibility, besides the use of different pathogen races, is
LeHSR2 03

HSR2 03

1

1
MVHDKQ

LeHSR2 03

51 AVKDVVAGENSGSRFRIYLPERNDSSVDKLPVILHFHGGGFCISQADWFM

HSR2 03

51 AVKDVVADEKSGSRLRIYLPERNDNSASKLPVILHFQGGGFCVSHADWFM

LeHSR203 101 YYAVYTRLARVANAIVVSVFLPLAPEHRLPAACDAGFAGLLWLRDVSREQ 150 ||$\cdot|||||| \cdot|\cdot||:||||||||||||||||||||:||||||:||:|$

HSR203 101 YYTVYTRLARAAKAIIVSVFLPLAPEHRLPAACDAGFAALLWLRDLSRQQ 150

LeHSR203 151 GHEPWLNEYADFNRVFLIGDSSGGNVVHQVSSARFGEEDLSPMSLAGSIPI

HSR2 03151 GHEPWLNDYADFNRVFLIGDSSGGNIVHQVAVKAGEENLSPMRLAGAIPI

LөHSR2 03201 HPGFMRSQRSKSELEQEQTPFLTLDMVDKFMELALPIGSTKDHPITCPMG

LөHSR203 251 DAAPAVEELKLPPYLYCVAEKDLIKDTEMEFYESLKTGEKDVELLINNGV

HSR203 251 EAAPAVEELKLPPYLYCVAEKDLIKDTEMEFYEAMKKGEKDVELFINNGV 300

\author{
LeHSR2 03301 GHSFYLNKIAVDMDPVTGSATEKLFEAIAEFINKH 335 \\ ||||||||||| |||||||.||||:||:||||||| \\ HSR203 301 GHSFYLNKIAVRMDPVTGSETEKLYEAVAEFINKH 335
}

Fig. 4. Comparison between the deduced amino acid sequences from Lehsr 203 and hsr203J. Solid line indicates residue identity. Dotted line indicates conservative substitutions of amino acids (Gribskov and Burgess 1986). GCG program "bestfit" was used for alignment. 
the use of a different plant cultivar (Samsun NN) that has a different genetic background: different bacteria- or plantencoded functions that are independent of hrp or R/avr gene functions can modulate their action. In fact, transgenic tobacco lines generated with the cultivar Samsun and containing the hsr203-GUS fusion show in some cases, low levels of GUS activity in response to various stress conditions, which is never observed in the original cultivar, Bottom Special.

Besides these genes or proteins that mediate the action of pathogenicity or avirulence factors, the role of the molecular determinants of host specificity was also investigated. In this context, we showed, with a pathosystem involving the avr $9 /$ Cf-9 interaction, that Lehsr 203 activation was dependent on the presence and/or functionality of the $R$ gene and observed in response to an avr gene product, AVR9. We also found that Lehsr 203 could be expressed in tomato in response to strains of Xanthomonas campestris pv. vesicatoria containing the avrBs3-2 deletion derivative causing a strong HR in tomato, and at later time points and at lower levels, in response to the same strain without the avirulence gene (data not shown). The kinetics and specificity of Lehsr 203 expression were clearly different in each case: rapid, transient, and highly specific in response to AVR9, later and preferential in response to $a v r B s 3$. It has been demonstrated recently that different $R$ gene- $a v r$ gene combinations can elicit distinct defense responses (Reuber and Ausubel 1996), and more particularly in the context of the tomato-Cladosporium fulvum interaction, that activation of intermediate responses such as superoxide production, lipid peroxidation, and salicylic acid biosynthesis can be differentially modulated, depending on the Cf-avr genes involved (Hammond-Kosack and Jones 1996;

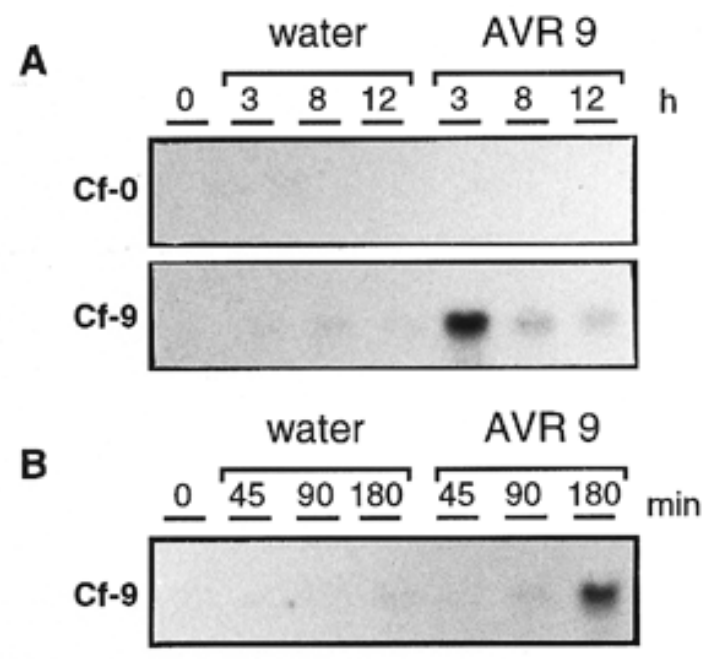

Fig. 5. Lehsr203 transcript accumulation in tomato plants infiltrated with intercellular fluids containing AVR9. A, Four leaves from two independent $C f-O$ (upper blot) or $C f-9$ (lower blot) tomato plants were infiltrated with a syringe without a needle, with either water or intercellular fluids containing AVR9, at a dilution 1/16 (AVR9). Infiltrated leaves were harvested $0,3,8$, or $12 \mathrm{~h}$ after infiltration. Hypersensitive response (HR) symptoms became visible $9 \mathrm{~h}$ after infiltration on $C f-9$ tomato plants. Total RNA ( $20 \mu \mathrm{g}$ per line) was hybridized with a DNA probe specific for Lehsr 203 RNA. B, Four leaves from two independent $C f-9$ tomato plants were infiltrated with either water or intercellular fluids containing AVR9, at a dilution 1/16 (AVR9). Infiltrated leaves were harvested $0,45,90$, or $180 \mathrm{~min}$ after infiltration. The same procedure as in A was then used.
May et al. 1996). In addition, a specific elicitor of the HR on tobacco, PopA1, was able to induce hsr203J expression similarly to $R$. solanacearum. However, other specific elicitors of fungal origin, namely elicitins, are less efficient elicitors of $h s r 203 \mathrm{~J}$, although they are significantly active, compared with elicitors such as the heptaglucoside from Phytophthora megasperma pv. glycinae. Moreover, their activity seemed to depend on the type of elicitor treatment, the developmental stage of the plant, and the environmental conditions (data not shown). Taken together, these results show clearly that $h s r 203$ activation is dependent on hrp functions and inducible by $a v r$ gene products, and that its extent depends on the nature of these functions. However, if the dependence of hsr203J activation on $h r p$ genes appears logical, in contrast, the expression of this gene in response to specific elicitors (PopA1) as well as nonspecific elicitors of HR (such as harpins) is more surprising. This result would be more in favor of a role in the HR-cell death than in the signal transduction pathway following the initial recognition events.

\section{hsr203 and programmed cell death during the HR.}

Several lines of evidence (Greenberg et al. 1994; Dietrich et al. 1994; Sugimoto et al. 1995; Mittler et al. 1995; Takahashi et al. 1989; Hammond-Kosack et al. 1994; He et al. 1993) suggest that cell death during the HR is a programmed cell death (pcd) process, resembling certain types of pcd in animal cells (Mittler and Lam 1996). But very little is known about the plant genes that regulate and participate in the rapid cell death that occurs during the HR. Cloning and characterization of genes responsible for the different lesion-mimic phenotypes such as Lls1 or LSD1 (Gray et al. 1997; Dietrich et al. 1997), together with functional analysis of plant homologs to genes that regulate pcd in animals, such as dad-1 (Sugimoto et al. 1995), will contribute to the elucidation of such a process. Recent studies indicate that HR activation in plants could be mediated by different rapid changes, such as the production of $\mathrm{H}_{2} \mathrm{O}_{2}$ (Levine et al. 1994), ionic fluxes (Nürnberger et al. 1994; Mittler et al. 1995), and protein phosphorylation (Dunigan and Madlener 1995), and could be developmentally regulated (Hammond-Kosack et al. 1994; Mittler et al. 1995). Our data indicate that exogenously supplied $\mathrm{H}_{2} \mathrm{O}_{2}$ was not sufficient to induce cell death, even at high concentrations (data not shown), or to significantly induce the activation of the $h s r 203 \mathrm{~J}-G U S$ fusion in transgenic tobacco leaves. This could be explained by the fact that plant cell suspensions were mostly used in previous reports, probably exhibiting different physiological properties, compared with cells found in leaves. An alternative would be that $\mathrm{H}_{2} \mathrm{O}_{2}$ and possibly related metabolites do not play a central role in cell death; molecular and genetic studies are required in order to elucidate the importance of the oxidative burst in the cell death. Finally, this result may suggest that a pathway not requiring $\mathrm{H}_{2} \mathrm{O}_{2}$ (ROS) is involved in the $h s r 203 \mathrm{~J}$ gene activation or that ROS is insufficient as a cell death activator under these conditions. Similarly, okadaic acid, a serine/threonine protein phosphatase inhibitor, was found to have no effect on cell death activation and on hsr203J expression, although it was found to affect cell death (Dunigan and Madlener 1995) and to induce the accumulation of several pathogenesis-related proteins in tobacco (Raz and Fluhr 1993; Desprès et al. 1995; Gianfagna and Lawton 1995). Absence or low levels of hsr203J expression were also observed after 
treatment with resistance-related signals such as salicylic acid or 2,6-dichloro-isonicotinic acid (INA) (Métraux et al. 1991), suggesting that $h s r 203$ activation would occur before or separate from the establishment of systemic acquired resistance, which can be a consequence of the HR.

In contrast, $h s r 203$ appears closely related to the cell death process, as indicated by our experiments with heavy metals and $b O$-expressing transgenic plants. In addition, hsr203 activation also appears at lower levels during the late stages of infection during compatible interactions, in conjunction with cell death due to the susceptible interaction, which is considered to be genetically programmed (Greenberg 1997). As we previously demonstrated that $h s r 203 \mathrm{~J}$ promoter activation closely matches with the pattern of bacterial ingress into the plant, and coincides well with the location of subsequently necrosed cells, the same observations could be made with the application of $\mathrm{CuSO}_{4}$ or $\mathrm{PbNO}_{3}$, infiltration of harpinproducing bacteria, or in older leaves of $b O$-expressing transgenic plants. These findings together with the distinctive regulation traits of $h s r 203$ during plant-bacteria interactions support the assumption that this gene might be activated during cell death not as a means for the cell to defend itself against the cell suicide program, but as an active participant or a regulator of the cell death process. Although these data do not demonstrate a direct role of this gene in the cell death process, they provide insights into the mechanisms involved in the activation of hsr203. Homology found in the coding sequence of this gene with conserved domains of serine hydrolases and functional characterization of the protein as an esterase (Baudouin et al. 1997) suggest either a role in the control of cell death or, more likely, a function in the establishment or limitation of the cell death. Such roles have been shown for proteases belonging to the ICE family in animal apoptosis (White 1996) and for endonucleases induced upon HR in tobacco (Mittler and Lam 1995). Identification of relevant substrates for $h s r 203$ family members will be important for establishing what kind of roles such hydrolases can play in the HR. A genetic approach has also been taken to address the requirement of $h s r 203$ expression in the HR.

\section{MATERIALS AND METHODS}

\section{Bacterial and fungal strains.}

All the $R$. solanacearum strains used in this study were kindly provided by C. Boucher (Arlat et al. 1992; Boucher et al. 1985). The GMI 1000 and K60 isolates are wild-type $R$. solanacearum strains. The former induces the development of an HR on tobacco leaves within 18 to $24 \mathrm{~h}$ of infiltration, and the latter causes the typical lethal wilting disease (Boucher et al. 1985). A derivative of the GMI 1000 isolate, called $\Delta$ hrp, deleted from the hrp gene cluster, causes no apparent symptom in inoculated leaves. All these strains were grown at $28^{\circ} \mathrm{C}$ in B or BGT media (Boucher et al. 1985).

P. syringae pv. pisi (CFBP 2105) and P. syringae pv. tabaci (CFBP 2106) strains were obtained from the Collection Française de Bactéries Phytopathogènes (L. Gardan, INRA, Angers, France). Pseudomonas fluorescens 55 containing or not pHIR11 encoding the hrpZ gene from $P$. syringae pv. sy-

Table 2. Effect of biotic and abiotic compounds on the activation of the $h s r 203 J$ promoter in transgenic tobacco plants

\begin{tabular}{|c|c|c|c|c|c|c|c|}
\hline \multirow[b]{3}{*}{ Compound } & \multirow{3}{*}{$\begin{array}{l}\text { Plant treatment and } \\
\text { compound concentration }\end{array}$} & \multicolumn{6}{|c|}{ GUS activity from transgenic lines (assay/control) } \\
\hline & & \multicolumn{2}{|c|}{ hsr203J } & \multicolumn{2}{|c|}{ str246C $\mathrm{C}^{\mathrm{a}}$} & \multicolumn{2}{|c|}{$\mathrm{CMACO1}^{\mathrm{a}}$} \\
\hline & & $6 \mathrm{~h}$ & $24 \mathrm{~h}$ & $6 \mathrm{~h}$ & $24 \mathrm{~h}$ & $6 \mathrm{~h}$ & $24 \mathrm{~h}$ \\
\hline Auxin $(2,4 \mathrm{D})$ & Absorption / $5 \mu \mathrm{M}$ & 1.0 & 1.0 & 0.5 & 26.5 & & \\
\hline Cytokinin (BAP) & Absorption / $5 \mu \mathrm{M}$ & 1.0 & 1.0 & 1.1 & 0.9 & & \\
\hline Cytokinin + auxin & Absorption / $5 \mu \mathrm{M}$ & 0.5 & 3.3 & 15.6 & 109.0 & & \\
\hline $\mathrm{ACC}$ & Absorption / $500 \mu \mathrm{M}$ & 1.2 & 0.6 & & & 1.6 & 2.9 \\
\hline \multirow{2}{*}{$\mathrm{CuSO}_{4}$} & Absorption $/ 100 \mu \mathrm{M}$ & 1.2 & 5.6 & 26.7 & 41.8 & & \\
\hline & Absorption / $500 \mu \mathrm{M}$ & 0.6 & 8.4 & 17.7 & 99.6 & & \\
\hline $\mathrm{PbNO}_{3}$ & Absorption / $10 \mathrm{mM}$ & 9.5 & 43.6 & & & & \\
\hline \multirow[t]{4}{*}{$\mathrm{H}_{2} \mathrm{O}_{2}$} & Absorption / $10 \mathrm{mM}$ & 1.0 & 1.0 & 1.8 & 0.8 & & \\
\hline & Absorption / $1 \mathrm{M}$ & 1.0 & 1.0 & 1.0 & 1.3 & & \\
\hline & Local infiltration / $10 \mathrm{mM}$ & 2.7 & 1.1 & 27.3 & 83.0 & & \\
\hline & Local infiltration / $1 \mathrm{M}$ & 1.0 & 2.3 & 22.0 & 49.2 & & \\
\hline \multirow[t]{2}{*}{$\mathrm{H}_{2} \mathrm{O}_{2} / \mathrm{ATZ}$} & Local infiltration $/ 10 \mathrm{mM}$ & 1.0 & 2.3 & 4.0 & 1.9 & & \\
\hline & Local infiltration / $1 \mathrm{M}$ & 1.0 & 4.8 & 5.9 & 6.2 & & \\
\hline ATZ & Local infiltration $/ 10 \mathrm{mM}$ & 0.7 & 3.3 & 2.6 & 3.6 & & \\
\hline \multirow[t]{2}{*}{ Salicylic acid } & Absorption / $70 \mu \mathrm{M}$ & 1.0 & 1.6 & 16.1 & 10.6 & & \\
\hline & Local infiltration / $3 \mathrm{mM}$ & 1.0 & 2.6 & 5.5 & 17.4 & & \\
\hline Methyl jasmonate & Local infiltration / $10 \mathrm{mM}$ & 1.0 & 1.0 & 5.2 & 1.6 & & \\
\hline INA & Absorption $/ 1 \mathrm{mg} / \mathrm{ml}$ & 1.0 & 1.0 & 3.8 & 6.3 & & \\
\hline Methyl-INA & Absorption $/ 1 \mathrm{mg} / \mathrm{ml}$ & 1.0 & 1.0 & 4.9 & 31.5 & & \\
\hline Okadaic acid & Absorption / $100 \mathrm{nM}$ & 3.1 & 1.1 & 1.9 & 4.8 & & \\
\hline Okadaic acid tetraacetate & Local infiltration / $100 \mathrm{nM}$ & 0.9 & 1.0 & 0.8 & 1.0 & & \\
\hline \multicolumn{8}{|l|}{ Ralstonia solanacearum } \\
\hline GMI 1000 & Local infiltration $/ 10^{7} \mathrm{CFU} / \mathrm{ml}$ & 45.3 & 210.8 & & & & \\
\hline K60 & & 1.0 & 6.9 & & & & \\
\hline
\end{tabular}

a Transgenic tobacco lines containing GUS fusions either with the $m s r$ gene promoter str246C (Gough et al. 1995) or with the ethylene biosynthesis gene promoter CMACO1 (Lasserre et al. 1996) have been used as positive controls. 
ringae was obtained from H. C. Huang (Huang et al. 1988). $P$. syringae and $P$. fluorescens strains were grown at $28^{\circ} \mathrm{C}$ in King's B broth or agar supplemented with the appropriate antibiotics (King et al. 1954).

Erwinia amylovora (CFBP 1430) strain was obtained from the Collection Française de Bactéries Phytopathogènes (L. Gardan, INRA, Angers, France). It was grown in LuriaBertani medium.

\section{Plant material.}

The Nicotiana tabacum L. cultivars used in this study were Bottom Special and Samsun NN. Transgenic tobacco plants containing the $h s r 203 \mathrm{~J}$ promoter-GUS fusion or the $b O$ transgene were previously described (Pontier et al. 1994; Mittler et al. 1995, respectively). Reciprocal crosses have been performed between two tobacco lines expressing the $b O$ transgene in Samsun NN background (EL301A and H; Mittler et al. 1995) and transgenic plants containing the hsr203J promoter-GUS fusion in Samsun NN background. Control crosses involved Samsun NN wild-type plants and hsr203J transgenic plants. The seeds were harvested and the kanamycin-resistant progeny analyzed. The presence and the expression of the $b O$ transgene was checked by Northern analysis. The presence and expression of the fusion was verified by GUS activity measurements after bacterial inoculation.

The seedlings were grown in vitro on Murashige and Skoog (MS) medium (Murashige and Skoog 1962) containing kanamycin $(500 \mathrm{mg} / \mathrm{ml})$ during 4 to 5 weeks $\left(25^{\circ} \mathrm{C}, 16\right.$-h photoperiod, $15 \mathrm{~W} \cdot \mathrm{m}^{-2}$ ), and then transferred to soil in a growth chamber $\left(25^{\circ} \mathrm{C}, 16\right.$-h photoperiod, $\left.30 \mathrm{~W} \cdot \mathrm{m}^{-2}\right)$. The cultivars of Lycopersicon esculentum used in this study were Moneymaker (Cf-0) and a near-isogenic line homozygous for $C f 9$ (Cf-9) provided by J. D. J. Jones (Hammond-Kosack et al. 1994). The seedlings were grown in 8 -cm-diameter peat pots containing horticultural humus, in a growth chamber $\left(25^{\circ} \mathrm{C}\right.$, 16-h photoperiod, $30 \mathrm{~W} \cdot \mathrm{m}^{-2}$ ).

\section{Inoculation procedures and plant treatments.}

Inoculation experiments were performed on at least two tobacco or tomato plants of the same genotype per experimental condition, and kanamycin-resistant $\mathrm{T}_{2}$ plants were used in the case of $h s r 203 \mathrm{~J}$ transgenic tobacco plants.

Two types of bacterial inoculation procedures were performed: vacuum or syringe infiltrations. The first one consists of infiltrating detached tobacco or tomato leaves (from 8- and 7-week-old plants, respectively) in vacuo with a bacterial suspension $\left(10^{7} \mathrm{CFU} / \mathrm{ml}\right.$ for Pseudomonas strains and $3.10^{7}$ $\mathrm{CFU} / \mathrm{ml}$ for Xanthomonas strains) or water as already described (Ragueh et al. 1989). Syringe infiltration experiments were performed on 8-week-old tobacco plants by infiltrating the bacterial suspension $\left(10^{8} \mathrm{CFU} / \mathrm{ml}\right)$ into a small region (1 $\mathrm{cm}^{2}$ ) of undetached leaves with a syringe without a needle. The same procedure was used to infiltrate intercellular fluids from a Cf-0-race 0 interaction (dilution 1/16) containing AVR9, kindly provided by J. D. J. Jones (Hammond-Kosack et al. 1994). Tobacco mosaic virus was inoculated by the classical procedure with Carborundum.

The elicitor preparations from bacterial and fungal origin were infiltrated at appropriate concentrations into transgenic tobacco leaves by the syringe infiltration procedure. Cryptogein and capsicein (Ricci et al. 1989) were infiltrated into to- bacco leaves in the presence of PMSF $(1.5 \mathrm{mM})$ at the concentration of $10 \mathrm{mg} / \mathrm{ml}$. An impure preparation of harpin (Wei et al. 1992) was used at dilution 1/50 in the appropriate buffer (PMSF $1.5 \mathrm{mM}$ ). The heptasaccharide from Phytophthora megasperma pv. glycineae (Sharp et al. 1984) was infiltrated at $1 \mathrm{mM}$. The PopA proteins were purified following the protocol described in Arlat et al. (1994) modified as follows: the filtered supernatant of strain GMI1000 carrying the hrp B regulator gene under the control of the Escherichia coli lac promoter was directly loaded on a $\mathrm{C}_{8}$ reverse phase liquid chromatography (RPLC) cartridge. The fractions eluting between 40 and $60 \% \mathrm{CH}_{3} \mathrm{CN}$ were pooled, diluted to a concentration of $20 \% \mathrm{CH}_{3} \mathrm{CN}$, and loaded on an Aquapore (Applied Biosystems, Roissy, France) $\mathrm{C}_{4}$ RPLC cartridge. The peak eluting at $45 \% \mathrm{CH}_{3} \mathrm{CN}$ was microsequenced and shown to correspond to PopA3. The same infiltration procedure was used for active oxygen species, salicylic acid, okadaic acid, and okadaic acid tetraacetate. Other compounds, such as hormones, heavy metals, methyl jasmonate, resistance inducers (CGA 41396 and CGA 41397), and salicylic acid, were applied by immersion of the stems of detached leaves from 8week-old soil-grown tobacco plants in the corresponding solutions. Leaves were then incubated under growth conditions.

\section{Isolation of the Lehsr 203 cDNA and nucleotide sequence analysis.}

A tomato (Hawaii 7996) genomic library was constructed into Lambda Dash TM vector by cloning 15- to $20-\mathrm{kb}$ Sau3A fragments (Stratagene, La Jolla, CA). From an aliquot of the amplified library, a recombinant pBluescript $\mathrm{SK}^{-}$phagemid stock was rescued by in vivo excision. Recombinant clones were isolated by plating with SURE $E$. coli host cells. The library was screened with the fragment $S a c \mathrm{I} / \mathrm{KpnI}$ of pNT239 (Marco et al. 1990).

Nucleotide sequencing was carried out on double-stranded templates according to the dideoxy chain termination method with Sequenase (USB, Cleveland, $\mathrm{OH}$ ). Sequence compilation and analysis were done with programs of the University of Wisconsin Genetic Computer Group (Gish and States 1993).

\section{RNA isolation and Northern analysis.}

RNA extraction and Northern analyses were previously described by Lummerzheim et al. (1993).

\section{GUS assays and microscopy.}

Plant tissue was ground in liquid nitrogen, homogenized in $1 \times$ GUS buffer, and centrifuged for $5 \mathrm{~min}$ at $10,000 \times \mathrm{g}$, and the supernatant was assayed for GUS activity, as previously described (Roby et al. 1990). Protein concentration was determined with the Bradford dye reagent. GUS activity was expressed as picomoles of 4-methylumbelliferone per min per $\mathrm{mg}$ of protein. Alternatively, histochemical assays were performed on fresh tissue with X-gluc (5-bromo-4-chloro-3indolyl- $\beta$-D-glucuronide; Clontech, Palo Alto, CA) as the substrate (Jefferson 1987). Samples were cleared by boiling in ethanol, and stored in ethanol $70 \%$.

For the detection of autofluorescent material, plant tissue was mounted on slides and observed with a Nikon EF-D optiphot epifluorescence microscope (Nikon, Tokyo) with UV (excitation filter, 330 to $380 \mathrm{~nm}$; dichroic mirror, $400 \mathrm{~nm}$; and barrier filter, $435 \mathrm{~nm}$ ). 

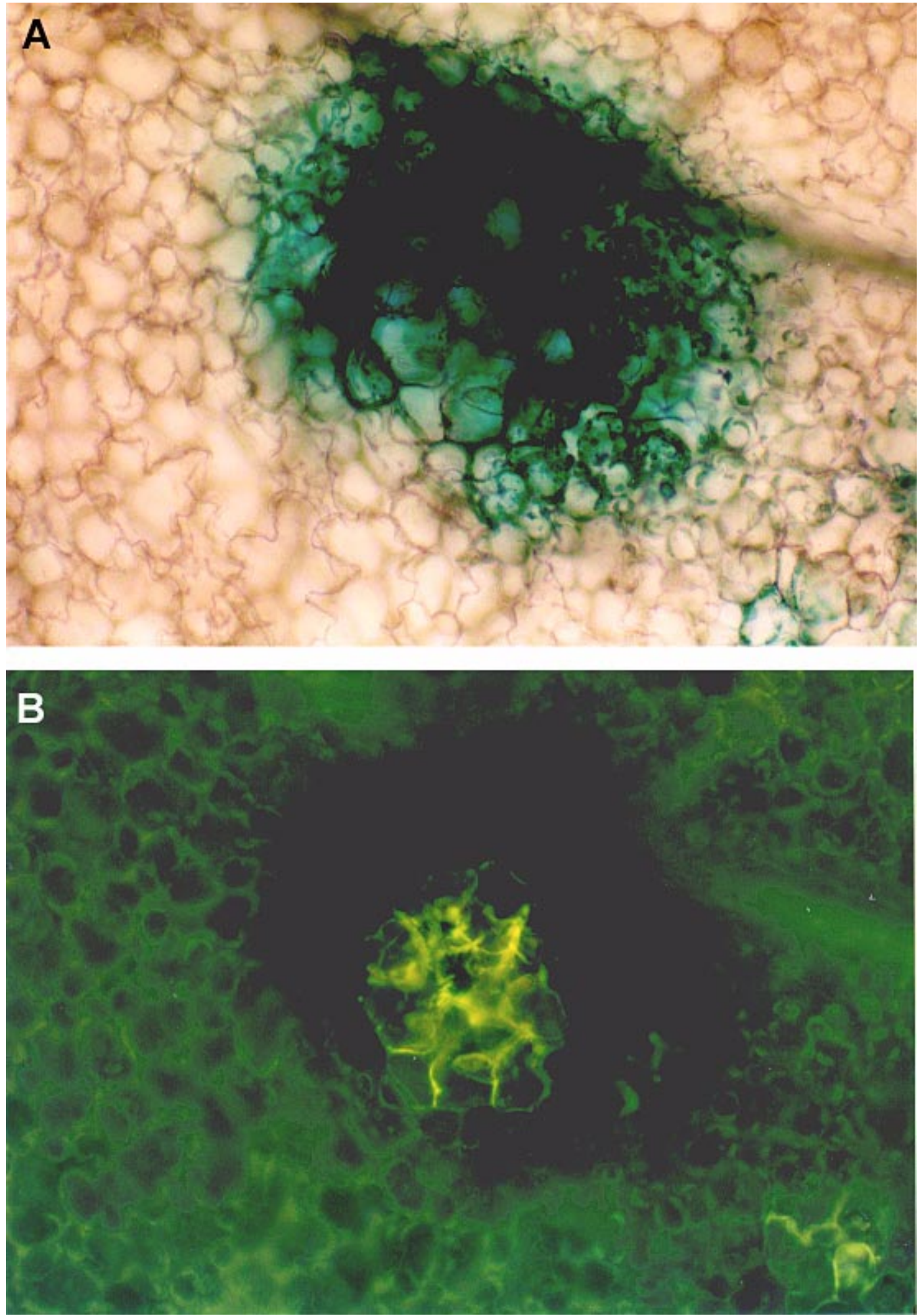

Fig. 6. Histochemical localization of $\beta$-glucuronidase $(G U S)$ gene expression in transgenic tobacco plants expressing the $b O$ gene. Older leaves showing spontaneous lesions, from progenies of crosses between $b O$ transgenic tobacco plants (EL301A) and transgenic ones containing an $h s r 203 \mathrm{~J}$ promoterGUS fusion (pHG21-14A) were stained for GUS activity. One representative sample with a developing lesion is shown either under normal light (A) or under UV light (B). Magnification used is $\times 10$. 
Ion leakage measurements.

Measurements of ion leakage were performed on five leaf disks ( $9 \mathrm{~mm}$ in diameter). They were floated abaxial side up on $3 \mathrm{ml}$ of distilled water for $4 \mathrm{~h}$ at room temperature. After incubation, the conductivity of the bathing solution was measured with a conductivity meter (model 604; VWR Scientific, New York).

\section{ACKNOWLEDGMENTS}

We gratefully acknowledge Sylvie Camut for excellent technical assistance. We thank Jonathan Jones and Kim Hammond-Kosack (The Sainsbury Laboratory, U.K.) for the tomato $C f-9$ and $C f-0$ lines and AVR9 extract, Claudine Balagué for the transgenic lines containing $C M$ ACO1, Frederique Van Gijsegem and Claudine Zishek (UMR CNRS/ INRA, Castanet-Tolosan, France) for the PopA1 preparations, and Hsiou Huang (National Chung Hsing University, Taiwan) for the Pseudomonas fluorescens strains. We are grateful to Harald Keller for the Phytophthora strains and the elicitins, and also for helpful discussions. This work has been supported by a grant from the French Ministère de l'Enseignement Superieur et de la Recherche (MESR) and a "Lavoisier" fellowship from the French Ministère des Affaires Etrangères to D. P., and in part by Hilleshög N.K., Sandoz.

\section{LITERATURE CITED}

Arlat, M., Gough, C. L., Zischek, C., Barberis, P. A., Trigalet, A., and Boucher, C. A. 1992. Transcriptional organization and expression of the large hrp gene cluster of Pseudomonas solanacearum. Mol. PlantMicrobe Interact. 5:187-193.

Arlat, M., Van Gijsegem, F., Huet, J. C., Pernollet, J. C., and Boucher, C. 1994. PopA1, a protein which induces a hypersensitive-like response on specific Petunia genotypes is secreted via the Hrp pathway of Pseudomonas solanacearum. EMBO J. 13:543-553.

Baudouin, E., Charpenteau, M., Roby, D., Marco, Y., Ranjeva, R., and Ranty, B. 1997. Functional expression of a tobacco gene related to the serine hydrolase family. Esterase activity towards short chain dinitrophenyl acylesters. Eur. J. Biochem. 248:700-706.

Bauer, D. W., Wei, Z.-M., Beer, S. V., and Collmer, A. 1995. Erwinia chrysanthemi EC16 harpin ${ }_{\mathrm{Ech}}$ : An elicitor of the hypersensitive response that contributes to soft-rot pathogenesis. Mol. Plant-Microbe Interact. 8:484-491.

Boucher, C., Gough, C., and Arlat, M. 1992. Molecular genetics of pathogenicity determinants of Pseudomonas solanacearum with special emphasis on hrp genes. Annu. Rev. Phytopathol. 30:443-461.

Boucher, C. A., Barberis, P. A., Trigalet, A. P., and Demery, D. A. 1985. Transposon mutagenesis of Pseudomonas solanacearum: Isolation of Tn5-induced avirulent mutants. J. Gen. Microbiol. 131:2449-2457.

Bowles, D. J. 1990. Defense-related proteins in higher plants. Annu. Rev. Biochem. 59:873-907.

Culver, J. N., and Dawson, W. O. 1991. Tobacco mosaic virus elicitor coat protein genes produce a hypersensitive phenotype in transgenic Nicotiana sylvestris plants. Mol. Plant-Microbe Interact. 4:458-463.

Dangl, J. L. 1995. Pièce de résistance: Novel classes of plant disease resistance genes. Cell 80:363-366.

Desprès, C., Subramanian, R., Matton, D. P., and Brisson, N. 1995. The activation of the potato $P R-10 a$ gene requires the phosphorylation of the nuclear factor PBF-1. Plant Cell 7:589-598.

Dietrich, R. A., Delaney, T. P., Uknes, S. J., Ward, E. J., Ryals, J. A., and Dangl, J. L. 1994. Arabidopsis mutants simulating disease resistance response. Cell 77:565-578.

Dietrich, R. A., Richberg, M. H., Schmidt, R., Dean, C., and Dangl, J. L. 1997. A novel zinc finger protein is encoded by the Arabidopsis LSD1 gene and functions as a negative regulator of plant cell death. Cell 88: 685-694.

Dunigan, D. D., and Madlener, J. C. 1995. Serine/threonine protein phosphatase is required for tobacco mosaic virus-mediated programmed cell death. Virology 207:460-466.

Flor, H. H. 1971. Current status of the gene-for-gene concept. Annu. Rev. Phytopathol. 9:275-296.

Gianfagna, T. J., and Lawton, M. A. 1995. Specific activation of soy- bean defense genes by the phosphoprotein phosphatase inhibitor okadaic acid. Plant Sci. 109:165-170.

Gish, W., and States, D. J. 1993. Identification of protein coding regions by database similarity search. Nature Genet. 3:266-272.

Godiard, L., Grant, M. R., Dietrich, R. A., Kiedrowski, S., and Dangl, J. 1994. Perception and response in plant disease resistance. Curr. Opin. Genet. Dev. 4:662-671.

Godiard, L., Ragueh, F., Froissard, D., Legay, J.-J., Grosset, J., Chartier, Y., Meyer, Y., and Marco, Y. 1990. Analysis of the synthesis of several pathogenesis-related proteins in tobacco leaves infiltrated with water and with compatible and incompatible isolates of Pseudomonas solanacearum. Mo. Plant-Microbe Interact. 3:207-213.

Goodman, R. N., and Novacky, A. J. 1994. The Hypersensitive Reaction in Plants to Pathogens: A Resistance Phenomenon. American Phytopathological Society, St. Paul, MN.

Gopalan, S., Wei, W., and He, S. Y. 1996. hrp gene-dependent induction of hin1: A plant gene activated rapidly by both harpins and the avrPto gene-mediated signal. Plant J. 10:591-600.

Gough, C., Hemon, P., Tronchet, M., Lacomme, C., Marco, Y., and Roby, D. 1995. Developmental and pathogen-induced activation of an $m s r$ gene, str246, from tobacco involves multiple regulatory elements. Mol. Gen. Genet. 247:323-337.

Gray, J., Close, P. S., Briggs, S. P., and Johal, G. S. 1997. A novel suppressor of cell death in plants encoded by the Lls1 gene of maize. Cell $89: 25-31$

Greenberg, J. T. 1997. Programmed cell death in plant pathogen interactions. Annu. Rev. Plant Physiol. Plant Mol. Biol. 48:525-545.

Greenberg, J. T., and Ausubel, F. M. 1993. Arabidopsis mutants compromised for the control of cellular damage during pathogenesis and aging. Plant J. 4:327-342.

Greenberg, J. T., Guo, A., Klessig, D. F., and Ausubel, F. M. 1994. Programmed cell death in plants: A pathogen-triggered response activated coordinately with multiple defense functions. Cell 77:551-564.

Gribskov, M., and Burgess, R. R. 1986. Sigma factors from E. coli, B. subtilis, phage SP01 and phage T4 are homologous proteins. Nucleic Acids Res. 14:6745-6763.

Hammond-Kosack, K. E., Harrison, K., and Jones, J. D. J. 1994. Developmentally regulated cell death on expression of the fungal avirulence gene $A v r 9$ in tomato seedlings carrying the disease-resistance gene $C f$ 9. Proc. Natl. Acad. Sci. USA 91:10445-10449.

Hammond-Kosack, K. E., and Jones, J. D. J. 1996. Resistance genedependent plant defense responses. Plant Cell 8:1773-1791.

He, S. Y., Huang, H. C., and Collmer, A. 1993. Pseudomonas syringae pv. syringae harpin ${ }_{\mathrm{Pss}}$ : a protein that is secreted via the Hrp pathway and elicits the hypersensitive response in plants. Cell 73:1255-1266.

Holt, C. A., Hodgson, R. A., Coker, F. A., Beachy, R. N., and Nelson, R. S. 1990. Characterization of the masked strain of tobacco mosaic virus: Identification of the region responsible for symptom attenuation by analysis of an infectious cDNA clone. Mol. Plant Microbe Interact. 3:417-423.

Huang, H. C., Schuuring, R., Denny, T. P., Atkinson, M. M., Baker, C. J., Yucell, T., Hutchinson, S. W., and Collmer, A. 1988. Molecular cloning of a Pseudomonas syringae pv. syringae gene cluster that enables Pseudomonas fluorescens to elicit the hypersensitive response in tobacco. J. Bacteriol. 170:4748-4756.

Jakobeck, J. L., and Lindgren, P. B. 1993. Generalized induction of defense responses in bean is not correlated with the induction of the hypersensitive response. Plant Cell 5:49-56.

Jefferson, R. A., Kavanagh, T. A., and Bevan, M. W. 1987. GUS gene fusions: $\beta$-glucuronidase as a sensitive and versatile gene fusion marker in higher plants. EMBO J. 6:3901-3907.

Keen, N. T., and Staskawicz, B. J. 1988. Host range determinants in plant pathogens and symbionts. Annu. Rev. Microbiol. 42:421-440.

Kiedrowski, S., Kawalleck, P., Hahlbrock, K., Somssich, I., and Dangl, J. L. 1992. Rapid activation of a novel plant defense gene is strictly dependent on the Arabidopsis RPM1 disease resistance locus. EMBO J. 11:4677-4684.

King, E. O., Ward, M. K., and Raney, D. E. 1954. Two simple media for the demonstration of pyocyanin and fluorescein. J. Lab. Clin. Med. 44:301-307.

Klement, Z. 1963. Rapid detection of pathogenicity of phytopathogenic pseudomonads. Nature 199:299-300.

Kombrink, E., and Somssich, I. E. 1995. Defense responses of plants to pathogens. Adv. Bot. Res. 21:1-33. 
Lasserre, E., Bouquin, T., Hernandez, J. A., Bull, J., Pech, J. C., and Balagué, C. 1996. Structure and expression of three genes encoding ACC oxidase homologs from melon (Cucumis melo L.) Mol. Gen. Genet. 251:81-90.

Levine, A., Tenhaken, R., Dixon, R., and Lamb, C. 1994. $\mathrm{H}_{2} \mathrm{O}_{2}$ from the oxydative burst orchestrates the plant hypersensitive disease resistance response. Cell 79:583-593.

Lozano, J. C., and Sequeira, L. 1970. Differentiation of races of Pseudomonas solanacearum by a leaf infiltration technique. Phytopathology 60:833-838.

Lummerzheim, M., de Olivera, D., Castresana, C., Miguens, F. C., Louzada, E., Roby, D., Van Montagu, M., and Timmerman, B. 1993. Identification of compatible and incompatible interactions between Arabidopsis thaliana and Xanthomonas campestris pv. campestris and characterization of the hypersensitive resonse. Mol. Plant-Microbe Interact. 6:532-544.

Lummerzheim, M., Sandroni, Castresana, C., M., de Oliveira, D., Van Montagu, M., Roby, D., and Timmerman, B. 1995. Comparative microscopic and enzymatic characterization of the leaf necrosis induced in Arabidopsis thaliana by lead nitrate and by Xanthomonas campestris pv. campestris after foliar spray. Plant Cell Environ. 18:499-509.

Marco, Y., Ragueh, F., Godiard, L., and Froissard, D. 1990. Transcriptional activation of 2 classes of genes during the hypersensitive reaction of tobacco leaves infiltrated with an incompatible isolate of the phytopathogenic bacterium Pseudomonas solanacearum. Plant Mol. Biol. 15:145-154.

May, M. J., Hammond-Kosack, K. E., and Jones, J. D. J. 1996. Involvement of reactive oxygen species, glutathione metabolism, and lipid peroxidation in the $C f$-gene-dependent defense response of tomato cotyledons induced by race-specific elicitors of Cladosporium fulvum. Plant Physiol. 110:1367-1379.

Métraux, J. P., Ahl-Goy, P., Staub, T., Speich, J., Steinemann, A., Ryals, J., and Ward, E. 1991. Induced systemic resistance in cucumber in response to 2,6-dichoro-isonicotinic acid and pathogens. Pages 432439 in: Advances in Molecular Genetics and Plant-Microbe Interactions. Vol. 1. H. Hennecke and D. P. Verma, eds. Kluwer Academic Press, Dordrecht, The Netherlands.

Mittler, R., and Lam, E. 1995. Identification, characterization and purification of a tobacco endonuclease activity induced upon hypersensitive response cell death. Plant Cell 7:1951-1962.

Mittler, R., and Lam, E. 1996. Sacrifice in the face of foes: Pathogeninduced programmed cell death in plants. Trends Microbiol. 4:10-15.

Mittler, R., Shulaev, V., and Lam, E. 1995. Coordinated activation of programmed cell death and defense mechanisms in transgenic tobacco plants expressing a bacterial proton pump. Plant Cell 7:29-42.

Murashige, T., and Skoog, F. 1962. A revised medium for rapid growth and bioassays with tobacco tissue cultures. Physiol. Plant. 15:473497.

Nürnberger, T., Nennstiel, D., Jabs, D., Sacks, T., Hahlbrock, K., and Scheel, D. 1994. High affinity binding of a fungal oligopeptide elicitor to parsley membranes triggers multiple defense responses. Cell 78: 449-460.

Osborne, B. A., and Schwartz, L. M. 1994. Essential genes that regulate apoptosis. Trends Cell Biol. 4:394-403.
Paulin, J. P., and Samson, R. 1973. Le feu bactérien en France. II. Caractères des souches d'Erwinia amylovora Winslow et al. 1920, isolées du foyer franco-belge. Ann. Phytopathol. 5:389-397.

Pontier, D., Godiard, L., Marco, Y., and Roby, D. 1994. hsr203J, a tobacco gene whose activation is rapid, highly localized and specific for incompatible plat/pathogen interactions. Plant J. 5:507-521.

Ragueh, F., Lescure, N., Roby, D., and Marco, Y. 1989. Gene expression in Nicotiana tabacum in response to compatible and incompatible isolates of Pseudomonas solanacearum. Physiol. Mol. Plant Pathol. 35:23-33.

Raz, V., and Fluhr, R. 1993. Ethylene signal is transduced via protein phosphorylation events in plants. Plant Cell 5:523-530.

Reuber, T. L., and Ausubel, F. M. 1996. Isolation of Arabidopsis genes that differentiate between resistance responses mediated by the RPS2 and RPMI disease resistance genes. Plant Cell 8:241-249.

Ricci, P., Bonnet, P., Huet, J.-C., Sallantin, M., Beauvais-Cante, F., Bruneteau, M., Billard, V., Michel, G., and Pernollet, J.-C. 1989. Structure and activity of proteins from pathogenic fungi Phytophthora eliciting necrosis and acquired resistance in tobacco. Eur. J. Biochem. 183:555-563.

Roby, D., Broglie, K., Cressman, R., Chet, I., and Broglie, R. 1990. Activation of a bean chitinase promoter in transgenic plants by phytopathogenic fungi. Plant Cell 2:999-1007.

Ryerson, D. E., and Heath, M. C. 1996. Cleavage of nuclear DNA into oligonucleosomal fragments during cell death induced by fungal infection or by abiotic treatments. Plant Cell 8:393-402.

Sharp, J. K., Valent, B., and Albersheim, P. 1984. Purification and partial characterization of a $\beta$-glucan fragment that elicits phytoalexin accumulation in soybean. J. Biol. Chem. 259:11312-11320.

Sugimoto, A., Hozak, R. R., Nakashima, T., and Rothman, J. H. 1995. dad-1, an endogenous programmed cell death suppressor in Caenorhabditis elegans and vertebrates. EMBO J. 14:4434-4441.

Takahashi, H., Shimamoto, K., and Ehara, Y. 1989. Cauliflower mosaic virus gene VI causes growth suppression, development of necrotic spots and expression of defense-related genes in transgenic tobacco plants. Mol. Gen. Genet. 216:188-194.

Van Gijsegem, F., Genin, S., and Boucher, C. 1993. Conservation of secretion pathways for pathogenicity determinants of plant and animal bacteria. Trends Microbiol. 1:175-180.

Vaux, D. L. 1993. Towards an understanding of the molecular mechanisms of physiological cell death. Proc. Natl. Acad. Sci. USA 90:786789 .

Walbot, V., Hoisington, D. A., Neuffer, M. G. 1983. Disease lesion mimics in maize. Pages 431-442 in: Genetic Engineering of Plants. T. Kosuge and C. Meredith, eds. Plenum, New York.

Wei, Z. M., Laby, R. J., Zumoff, C. H., Bauer, D. W., He, S. Y., Collmer, A., and Beer, S. V. 1992. Harpin, elicitor of the hypersensitive response produced by the plant pathogen Erwinia amylovora. Science 257:85-88.

White, E. 1996. Life, death, and pursuit of apoptosis. Genes Dev. 10:1-15.

Wolter, M., Hollricher, K., Salamini, F., and Schulze-Lefert, P. 1993. The mlo resistance alleles to powdery mildew infection in barley trigger a developmentally controlled defence mimic phenotype. Mol. Gen. Genet. 239:122-128. 